\title{
Review on the Effect of Deep Cryogenic Treatment of Metallic Materials in Automotive Applications
}

\author{
Patricia Jovičević-Klug ${ }^{1,2, *[1}$ and Bojan Podgornik ${ }^{1,2}$ \\ 1 Department of Metallic Materials and Technology, Institute of Metals and Technology, Lepi pot 11, \\ Ljubljana 1000, Slovenia; bojan.podgornik@imt.si \\ 2 Jožef Stefan International Postgraduate School, Jamova cesta 39, Ljubljana 1000, Slovenia \\ * Correspondence: patricia.jovicevicklug@imt.si; Tel.: +386-1-4701-990
}

Received: 2 March 2020; Accepted: 24 March 2020; Published: 26 March 2020

\begin{abstract}
With the development of society, every year there are increasing demands in the automotive industry on cost savings, environmental safety, reduction of raw material consumption, performance improvement, material life cycle and recycling of components. In this review, emphasis is given on ferrous and non-ferrous alloys, which are used as components, where both groups can be treated by deep cryogenic treatment (DCT). DCT has shown to increase hardness, tensile strength and wear resistance, reduce density of defects in crystal structure, improve toughness and corrosion resistance. Though, some researchers also reported results that showed no change in material properties, or even deterioration of material properties, when subjected to DCT. This additionally points out to lack of consistency and reliability of the DCT process, which is needed for its successful incorporation in automotive applications. However, to prove with certainty the resulting outcome on the material properties and knowledge about the reasons for the variation of this effect on metallic materials, further approach and testing with different variables should be conducted in the future. This review provides a synopsis of different approaches of DCT on different materials for automotive applications in order to indicate effects on the material performance during DCT.
\end{abstract}

Keywords: deep cryogenic treatment; DCT; automotive applications; ferrous alloys; non-ferrous alloys; properties

\section{Introduction}

With development of society and science, every year newly-developed metallic materials are presented for automotive applications as a response to an increasing demand on environment safety, reduction of material consumption, recycling of the material, improvement of material life cycle performance and, particularly, cost savings [1-4]. Selection of materials for automotive applications is influenced by the demand on fuel/energy consumption reduction, operating conditions and application, costs saving and maintenance. Additionally, market demands on driving comfort, safety and every year's new designs of the vehicles, give rise to many additional parameters to be fulfilled by the selected material $[5,6]$. To cope with these increasing demands, different approaches on enhancement of properties of metallic materials are being developed nowadays. One common branched technique is heat treatment. Heat treatment is a practice of exposing a material for a certain amount of time to a specific temperature by warming and/or cooling, predominantly of metallic material, in order to achieve particular changes of the targeted material. The most common technique of heat treatment for automotive applications applies processing temperature set higher than $0{ }^{\circ} \mathrm{C}(>273 \mathrm{~K})$. However, in the last century, individual attempts to utilize subzero treatment also known as cryogenic treatment were conducted. The main aim of cooling down metallic material to subzero $(<273 \mathrm{~K})$ temperatures was to remove residual stress and to increase wear resistance of the treated material $[7,8]$. However, in 
later development of the technique various other properties such as strength, hardness and corrosion resistance have been reported to change and added to the designated properties to be manipulated during subzero treatment. One of the jewels of subzero treatments is the deep cryogenic treatment (DCT), which is also the main topic of this review.

\section{Cryogenic Treatment and Metallic Materials for Automotive Applications}

\subsection{Cryogenic Treatment}

The word cryogenic originates from two Greek words: "Kryo", which stands for very cold, and "genics", which represents to produce. So, cryogenic treatment is a method, where material gets cooled to temperature below $0{ }^{\circ} \mathrm{C}(<273 \mathrm{~K})$ to induce specific properties of the material [9]. The common names for cryogenic treatment found in the literature are: Cryo, Cryo-treated, subzero, sub-zero, low temperatures treatment, ultra-low temperatures, cryogenics, cryogenic processing, cryoprocessing, cold treatment, cryogenically treated, cryogenating, cryogenic stress relief, cryogenic hardening, and cryogenic thermal cycling treatment [10-18]. As various as the naming, also the applicability of cryogenic treatment is numerous, ranging from fabrication processes (3D printed objects [19], electrodes [20], welded joints [21] etc.), down to material removal processes (grinding [22], drilling [23] and milling [24]) and metal forming processes (manufacture of tools or components [25]). In last few years, applications of cryogenic treatment in nanosciences and nanotechnologies of metallic materials are used for automotive applications as a part of the heat transfer applications, where the main aim is to resolve the agglomeration of particles [26]. The applications of cryogenic treatment have evolved throughout the last century, from treating whole components of a machine to individual part of tools or even specific nanomaterial structures for application or integration into other materials. Furthermore, nowadays interdisciplinary research has become more focused on cryogenic treatment to make an advance step in understanding of material manipulation with such treatment in different disciplines or industries, such as medicine, space, music and automotive industry $[2-4,20,27]$.

Life and performance of a specific automotive component greatly depends on proper design, selection of material, accuracy of production, and application of selected heat treatment, which at the end is subject to production costs [28-30]. In automotive industry, ferrous metals (steels) and non-ferrous alloys (aluminum, titanium, magnesium, nickel etc.) are used as components, where both groups can be treated by cryogenic treatment. Automotive components, made of this raw material, are timing gears, crown wheel, crown pinion, bevel wheel, king pin, pinion shaft, bevel pinion, differential turnion, crankshafts, connecting rods, axle, etc. [31-33]. The idea of every industry, including the automotive industry, is to reduce costs of manufacturing and to obtain the quality of the final products. For example, in every passenger vehicle there are several parts (some described above) that are continuously exposed to fatigue and wear and are usually hard to produce and need specialized lubrications and proper lubricant to prevent failures [31].

Cryogenic treatment can provide solutions to such problems as it improves thermo-chemical, mechanical and tribological properties [17,32], leading to higher obtained product qualities and competitiveness, whilst retaining lower production and maintenance costs. The costs of production are an important factor as it influences the selection of the material and process that determine the possible failure of a material due to different wear mechanisms [33]. DCT can reduce production costs as DCT changes (improves) properties of material or component. Furthermore, a DCT cycle can potentially be used to replace a portion of the tempering cycle(s), which reduces processing costs and minimizes equipment set up (even up to $50 \%$ of cost reduction) $[15,34,35]$. During cryogenic treatment, not only wear reduction, but also other mechanical properties, such as dimensional stability, ductility, hardness, residual stress, toughness, strength and fatigue can be improved [1,7,8,29,36-38].

Conventional cryogenic treatment is a gradual cooling of the metallic material or component to predetermined subzero temperature, then maintaining the selected temperature for a specific time and eventually, gradually warming up, to bring material or component back to room temperature at 
$20-25^{\circ} \mathrm{C}(293-298 \mathrm{~K})$ [8]. It is commonly recognized that cooling and warming rates of the metallic materials should be kept constant to improve properties and to avoid thermal micro-cracking $[28,39]$. Cryogenic treatment is an affordable permanent treatment process of metallic material that can be applied only once, but affects the entire cross section of the material and can at the same time replace additional procedure (example: single tempering step instead of double or triple tempering) [34].

Cryogenic treatment consists of the following sequence [40,41] (Figure 1):

(1) Slow cooling to predetermined temperature (descent, slow cooling keeps the stress to a minimum).

(2) Soaking period for pre-determined time with uniform or cycling temperature profile [41,42].

(3) Slow warming up to room temperature (ascend; slow warming rate keeps the stress to a minimum).

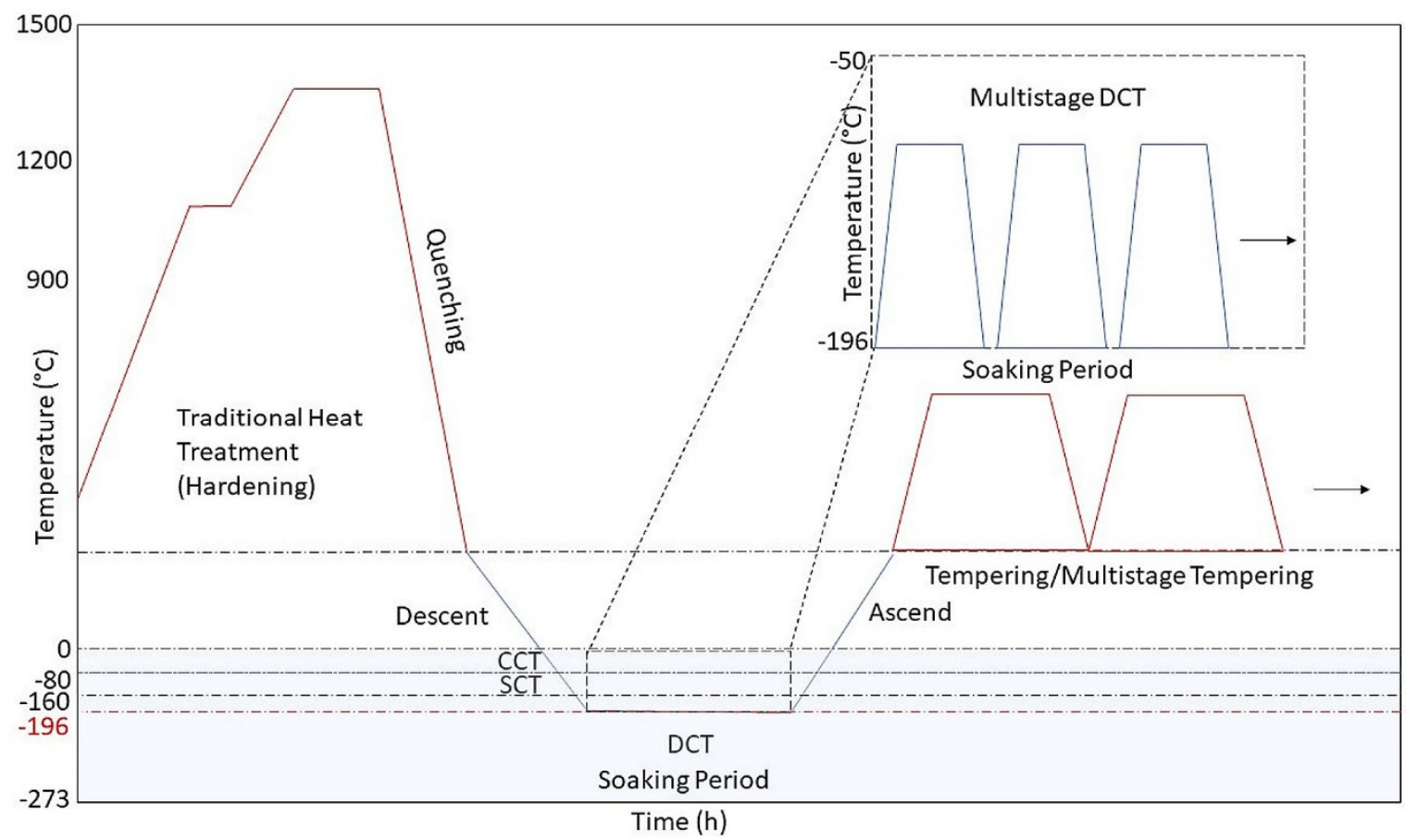

Figure 1. This figure represents the scheme of the most conventional cryogenic treatment process, with included preparation and post-preparation (warming and cooling) of the metallic material. With added different possibilities of the method. Dashed lines mark the limit temperatures of various cryogenical treatments (conventional cold treatment (CCT), shallow cryogenic treatment (SCT) and deep cryogenic treatment (DCT)).

\subsection{Types of Cryogenic Treatment}

The cryogenic treatment is divided into three systematically different temperature systems. First and foremost used is conventional cold treatment (CCT), where temperature is reduced down to $-80{ }^{\circ} \mathrm{C}(\geq 193 \mathrm{~K})[1,7]$. CCT was common in the past, because it was believed that temperatures till $-80^{\circ} \mathrm{C}(\geq 193 \mathrm{~K})$ were adequate to transform most of the retained austenite into the martensite in steels, establishing improved fatigue strength and dimensional stability and increased wear performance $[40,41]$. Shallow cryogenic treatment (SCT) occurs from -80 to $-160{ }^{\circ} \mathrm{C}(193$ to $113 \mathrm{~K})$ [34,43-45]. In Celsius scale, the deep cryogenic treatment (DCT) is in some literature below $-160{ }^{\circ} \mathrm{C}(113 \mathrm{~K})$ [46] and other literature $-153{ }^{\circ} \mathrm{C}(120 \mathrm{~K})[47,48]$, depending on the corresponding author. DCT can be also found in literature named as sub-zero treatment (SZT) [42] or ultra-low temperature process (ULTP) [18]. In SCT, the metallic material is placed after quenching directly below $-80^{\circ} \mathrm{C}$ for predetermined period to reach thermal equilibrium. SCT causes transformation of retained austenite into martensite (increase in hardness) and allows size reduction of carbides as well as increases the number of precipitated carbides in the microstructure [49]. 


\subsection{Deep Cryogenic Treatment}

DCT of metallic materials is reported to induce the conversion of retained austenite into martensite, carbon redistribution and site reduction [46], reduction of free energy of crystal structure [50], precipitation of fine submicroscopic carbides $[22,23,25,29,41,51]$ and precipitation of secondary and tertiary carbides [46,52-54]. DCT is a very valuable tool, when dealing with the improvement of the material's properties. On the effectiveness of the DCT on selected material and its properties influence different factors such as selected cryogenic temperature $(72 \%)$, holding time (soaking period) $(24 \%)$, cooling and warming rate $(10 \%)$ and sequence of DCT $(2 \%)[8,55-57]$. The factor importance was based on wear resistance and then calculated statistically with Taguchi method, where the aim was to identify the importance of each critical parameter (cooling/warming rate, soaking temperature, soaking time, tempering time, placement of DCT) and its mechanism [57]. Beside these factors, influence on the performance of DCT have also the material chemical composition [58,59], temperature of austenization or solution treatment [60] and tempering and aging temperature [61]. These individual parameters dictate the efficiency of DCT and the individual evolution of certain phases in treated material, leading to a great impact on the resulting properties of the material. The sequence of cryogenic treatment is usually applied after quenching of metallic material $[28,62,63]$, but there are also studies where the treatment was implemented after annealing [64], or even after tempering $[65,66]$. In recent literature, a specific type of DCT is described as multistage cryogenic treatment (Figure 1), where treatment consists of repeated rapid cooling down to DCT temperature (below $-196^{\circ} \mathrm{C}$ ) and re-heating up to SCT temperature $\left(-80^{\circ} \mathrm{C}\right)$ or even to room temperatures $\left(20^{\circ} \mathrm{C}\right.$ or more) $[67,68]$.

\section{Metallic Materials Used for Automotive Applications}

Metallic materials, which have undergone DCT in research studies and have applications in automotive industry are ferrous (different grades of steel) (Table 1) and non-ferrous (aluminum, magnesium, nickel, and titanium alloys) (Table 2) alloys.

\subsection{Ferrous Materials for Automotive Applications}

Traditional use of steels in the automotive industry, is a result of formability, longer life, low production costs, adaptability to corrections, susceptibility to modifications in strength level, recyclability, good crash energy absorption and ease of joining [69]. On average, 900-1090 kg of steel (different grades) is used per one single car. This includes body structure (doors, trunk, panels) (34\%), drive train (engine block, wear resistance gears) (23\%), suspension (12\%), the remaining $31 \%$ is in tank, tires, wheels, breaking and steering system of the car. The plan for future steel vehicles (FSV) is to reduce body mass of the car to only $188 \mathrm{~kg}$, but at the same to maintain the properties of the previous form body [70,71]. However, usually these new materials for FSV are more expensive, complex (steel, matrix, non-ferrous alloy, composites), have no corrosion resistance, have limited service life and are more difficult to produce, and at the same time it is harder to maintain their properties [71]. Many of these difficulties could be overcome by the application of a variety of new methods dealing with the improvement of steels (coating, DCT etc.).

An overview (Table 1) of the literature indicates the variety of ferrous materials used as reference materials for DCT in research for automotive applications. The materials have been tested and investigated only individually and were conducted without any repeated experiments following up on the presented results of the research.

From the summary given in Table 1 , the soaking temperatures of applied DCT vary from -150 to $-196{ }^{\circ} \mathrm{C}[3,47,53,72-77]$, depending on each author and research. For example, research from Surberg et al. $2008[48,77]$ is already between SCT and DCT, so that interpretation of results cannot clearly provide description of the effect of DCT on the metallic material. The temperature is the most important factor $(72 \%)$, which influences on the effect of DCT on the selected metallic material and thus it is important to use temperatures that are more consistent to attain comparable results between 
studies and with it the effect of DCT on a particular material. Holding time (24\%) of experiments is in most cases $24 \mathrm{~h}$ [72,74-77], but some divergences can also be found such as 0.5, 2, 16 and more than $40 \mathrm{~h}[3,53,73]$. Holding time is the second factor, which influences on the effect of DCT on metallic material. However, the variety of time periods applied on the steel show that the mechanism and dynamics of DCT is still not well understood, as some studies get the same resulting effect with shorter holding time $[3,47,73]$ and others with longer soaking period. Cooling and warming rate in conducted studies differs from 0.25 [47] to $3{ }^{\circ} \mathrm{C} / \mathrm{min}$ [53]. Even though the generally accepted recommended cooling and warming rate is $0.5^{\circ} \mathrm{C} / \mathrm{min}[28,39]$. This again demonstrates that there is no systematic approach to DCT and thus variety of approaches and explanations are expected and occurring.

Table 1. Ferrous materials and deep cryogenic treatment (DCT) parameters from the literature.

\begin{tabular}{|c|c|c|c|c|c|}
\hline Ferrous Material & Reference & $\begin{array}{c}\text { Temperature } \\
\left({ }^{\circ} \mathrm{C}\right)\end{array}$ & $\begin{array}{l}\text { Holding Time } \\
\text { (h) }\end{array}$ & $\begin{array}{l}\text { Cooling Rate } \\
\left({ }^{\circ} \mathrm{C} / \mathrm{min}\right)\end{array}$ & $\begin{array}{c}\text { Warming Rate } \\
\left({ }^{\circ} \mathrm{C} / \mathrm{min}\right)\end{array}$ \\
\hline EN52 steel & [72] & -188 & 24 & 1 & 0.6 \\
\hline $21-4 \mathrm{~N}$ valve steel & [72] & -188 & 24 & 1 & 0.6 \\
\hline super-bainitic steel & [73] & -196 & 2 & NP & NP \\
\hline 1.1189 steel & [3] & -196 & 0.5 & NP & NP \\
\hline 1.2379 steel & [67] & -180 & 24 & NP & NP \\
\hline 1.4418 steel & {$[78,79]$} & -196 & 1,20 & 0.7 & 0.25 \\
\hline 1.611 steel & [74] & -196 & 24 & 1.8 & 1.8 \\
\hline 1.6523 steel & [53] & -185 & 16 & 3 & 3 \\
\hline 1.6566 steel & [75] & -196 & 24 & 1.26 & 0.64 \\
\hline 1.7147 steel & [76] & -196 & 24 & 1.24 & 0.64 \\
\hline 1.7139 steel & [48] & -150 & 24 & NP & NP \\
\hline 1.7225 steel & [66] & -196 & 24 & 1.26 & 0.64 \\
\hline
\end{tabular}

\subsection{Nonferrous Materials for Automotive Applications}

Non-ferrous alloys are largely present in a vehicle as components of anti-lock braking system (ABS), body panels, cylinder heads, pistons, power train, indoor structure, transfer case, wheel core, car seat frame, electro-mechanical applications etc. [80]. One of the advantages of non-ferrous alloys is that they are mostly lighter as compared to ferrous alloys. Aluminum alloys are also more corrosion resistant compared to traditional steel components. In recent years, magnesium, nickel and titanium alloys are getting more attention in the automotive industry. Magnesium alloys can be mostly found in racing cars (very light material and contribute to saving fuel), for example, in Porsche 917, $133 \mathrm{~kg}$ of its total weight is attributed to components made of magnesium alloys [5]

A synopsis of the literature on the non-ferrous alloys exposed to DCT presented in Table 2 provides interesting outcome, demonstrating that not much research has been conducted in the field of DCT in combination with non-ferrous alloys. This is shown by the scarce amount of studies conducted with a much limited amount of different alloys researched in terms of DCT effect [81-86]. The overlook of the results verified, that research of non-ferrous alloys is still, more or less at the beginning, even though some studies on non-ferrous alloys were conducted by National Aeronautics and Space Administration (NASA) in 1950s-2000s of aluminum alloys for space industry [87]. However, due to market demands, the development and need of non-ferrous alloys in automotive, space, medicine etc. industry will reemerge. As a consequence, more studies will be promoted in the field of cryogenic treatment and behavior of selected alloys. 
Table 2. Non-ferrous alloys in the literature.

\begin{tabular}{|c|c|c|c|c|c|}
\hline Nonferrous Material & Reference & $\begin{array}{c}\text { Temperature } \\
\left({ }^{\circ} \mathrm{C}\right)\end{array}$ & Holding Time (h) & $\begin{array}{l}\text { Cooling Rate } \\
\left({ }^{\circ} \mathrm{C} / \mathrm{min}\right)\end{array}$ & $\begin{array}{c}\text { Warming Rate } \\
\left({ }^{\circ} \mathrm{C} / \mathrm{min}\right)\end{array}$ \\
\hline Ti-6Al-4V alloy & [89] & $\mathrm{NP}$ & NP & NP & NP \\
\hline Ti-6Al-4V alloy & [83] & -180 & 2 & 1.7 & 1.7 \\
\hline 6061 and 6082 aluminum alloy & [84] & -163 & NP & NP & NP \\
\hline 6101 aluminum alloy & [88] & -190 & 12 & NP & NP \\
\hline
\end{tabular}

Observation showed that selected soaking temperatures of applied DCT on non-ferrous alloys is in the range of -163 to $-196{ }^{\circ} \mathrm{C}$, being about $10^{\circ} \mathrm{C}$ lower than in average used for ferrous alloys in automotive industry $[81-86,88]$. This indicates, that lower temperatures are apparently needed, when dealing with non-ferrous alloys. The possible explanation could be in the absence of carbon and the much different phase formation mechanisms found in non-ferrous alloys. Soaking time of experiments is in the most cases longer than $20 \mathrm{~h}[82,85]$, but there can be found also shorter holding times, for example, 2, 4, 8, 12, $16 \mathrm{~h}[82,83,88]$. This could also indicate that longer time is needed for improvement of the properties of the non-ferrous alloys compared to ferrous alloys. Cooling and warming rates in conducted studies differs from 0.5 [85] to $20^{\circ} \mathrm{C} / \mathrm{min}$ [82]. The guidelines for application of DCT on non-ferrous alloys are also spare and are not systematically approached.

\section{Effect of Deep Cryogenic Treatment on Metallic Materials for Automotive Applications}

In the automotive industry, materials and components have been exposed to CCT, SCT and DCT through the years. On one hand, CCT transforms most of the retained austenite into the martensite in steels, establishing improved fatigue strength, due to increased material strength [74] and formation of fine martensitic structures that lead to dislocations pinning [91]. Additionally, CCT has shown to also improve dimensional stability and increase wear performance $[40,41]$. SCT, on the other hand, causes transformation of residual retained austenite into martensite (increase in hardness), inducing secondary precipitated carbides with homogeneous distribution [49]. Various steels for automotive applications have been exposed also to the lowest subzero temperatures with DCT. In some cases, DCT has improved the properties of steels and also non-ferrous alloys, reduced production costs and made machinability easier. But in other cases properties improvement of metallic materials were insignificant $[48,82]$ or even deteriorated [74,75]. The DCT improves dimensional stability [72,73], resistance to electro-chemical corrosion [72], hardness [3,73,74], wear resistance [3,74,81,85], machining time and machinability [3], impact toughness [47], free energy absorption [74], ductility [83,84] and smooth surface of alloys is improved [82]. Furthermore, it provides more homogeneous and finer distribution of precipitated secondary carbides $[53,75]$.

When explaining the reason for change in the properties of the steel when treated by DCT, different theories have been proposed. Jaswin and Mohan Lal (2015) [72], Bensely et al. (2006) [13] and Kumar et al. (2016) [86] (concerning the metal matrix) proposed that the main reason of improvement is attributed to grain refinement and precipitation of very fine carbides. This mechanism is attributed to the formation or better say precipitation of $\eta$-carbides, instead of $\varepsilon$-carbides in conventional heat treatment (Meng et al. (1994)) [92]. The next possible mechanism described by Coolins (1996) [49], is the influence of DCT on production of internal stresses, which are a result of transformation of austenite to martensite. Internal stresses may spawn twins and dislocation in crystal lattice defects. Huang et al. (2003) suggested that super saturation of martensite at DCT increases its lattice distortion and thermodynamic instability due to the extremely low temperature, which then promotes carbon and alloying elements atoms to separate at the nearby crystal defects. Akhbarizadeh et al. (2009) also explained that another possible explanation is induced carbide precipitation caused by martensite and austenite lattice contraction. As a result of martensitic contraction and conditioning, residual stresses 
in the material change into a more compressive character [93]. This has been shown to have positive effect on steels, as DCT reduces tensile residual stresses or even forms compressive stresses that benefit material performance and lifetime [94].

Hu et al. (2014) [73] explained that the new properties are consequences of refinement of retained austenite. When talking about influence of retained austenite as the mechanism that stands behind the change of properties, it must be distinguished between blocks and thin films of retained austenite in the observed steel. Films of retained austenite have higher carbon content than blocks of retained austenite [95]. Where both types can be later transformed into martensite and thus, it is believed that martensite has also different orientation than austenite in the DCT. During DCT, both types of retained austenite are divided into newly formed smaller martensite regions. Coarser retained austenite is therefore formed by refinement by DCT.

Koneshlou et al. (2011) [96] and Prudhvi et al. (2016) [3] concluded that the main mechanism behind the DCT is also the transformation of austenite to martensite, where smaller martensite laths are uniformly formed in the matrix. Niessen et al. (2018) [47] provided useful input on the thermal formation of the martensite from austenite, from which strong influence of holding time on properties of steel has been indicated, especially in terms of impact toughness. Zhirafar et al. (2007) [74] explained changed properties after DCT by the higher amount of the "freshly-formed" martensite.

Moreover, in their study it was also observed that DCT causes detrimental effect on the impact toughness, which is contradictory with the observation by Niessen et al. (2018) [47]. Dhokey et al. (2014) similarly as Zhirafar et al. (2007) suggested possible explanation, which could be in the mechanism behind the change of properties is densified martensite, precipitation of secondary martensite and precipitation of fine carbides. Precipitation of secondary martensite may occur because of martensitic transformation during DCT. The other explanation could be also that secondary martensite is formed after DCT, during tempering, where the assumption is that the relief of phase hardening stimulated precipitation of secondary martensite forms [97]. Surberg et al. (2008) [48] also stated that, in their research, DCT had insignificant effect on the core properties of the investigated steel, which is quite an interesting result, as DCT is usually applied to affect the properties from the superficial layer to the core. Author suggested that the ineffectiveness of DCT resulted from the core, which contained retained austenite, regardless of the applied treatment. In most cases the modification of the upper most layers is performed by other surface engineering techniques (i.e., plasma nitriding), which are used in the combination with DCT.

In non-ferrous alloys it is predicted that changes induced by DCT are contributed to displacement of crystallographic plane during DCT in relation to plastic deformation, which can be explained by military atomic movement [81]. Hu et al. (2018) [82] and Gu et al. (2013) [83] suggested that the reason for alterations in the titanium alloy properties is in the precipitation of $\alpha$ titanium particles in the matrix, which is activated by the contraction of transformation kinetics of the $\beta$ phase. Contraction of $\beta$ phase is faster than $\alpha$ phase during DCT. Additionally, the solubility of vanadium drops significantly, and as a consequence, the in metastability of $\beta$ phase changes and its transformation into stable $\alpha^{\prime}$ and $\beta^{\prime}$ phase occurs. Gu et al. (2013) [83] also proposed that the reason behind changes is also in the reduction of quantities of $\beta$ phase particles and increase of grain size. Hu et al. (2018) [82] also exposed that DCT had little effect on the hardness of the titanium alloy, which could be the consequence of phase change and the higher shear strength. Park et al. (2015) [84] also suggested that the number and size of precipitated particles in aluminum alloys could be the explanation for modified characteristics. Asl et al. (2009) [85] observed similar phenomena on magnesium alloy, where morphology of $\beta$ particles also plays an important role in the transformation of the material's properties, where coarse separated eutectic $\beta$ phase penetrates in the matrix.

\section{Contradictory Existing Researches for Application of DCT for Automotive Applications}

Nowadays, contradictory results can be found in several studies implementing DCT technique for automotive applications, which lead to a lack of consistency and reliability of the DCT as a treatment 
process, which is needed for integration in modern and future industry. First possible explanation is in the unsystematic approach to DCT. This can be seen in different soaking times, soaking temperatures, different placement of DCT processing route, and as well as different cooling or warming rates. Second probable reason lays in different grades of steel and types of non-ferrous alloys used for different researches, where each grade has specific chemical composition, requiring different heat treatment parameters. Moreover, with the integration of DCT established heat treatment parameters (austenitizing temperature, quenching rate and tempering temperature) must also be adapted and optimized. Third reason could be in measuring errors and poor and inconsistent interpretation, which at the end lead to different results of DCT. The previously mentioned errors could also occur due to the different methodologies used in industry and at research institutions when studying DCT. In basic research, the selection, machining and heat treatment of the material is carefully monitored and carried out.

\section{Conclusions}

This review study indicated possible effects of DCT on the material performance and properties. Moreover, this review presents a synopsis of current results and future possibilities for evolution and standardization of DCT method for automotive applications. The most relevant conclusions can be condensed as follows:

- Hardness and wear resistance improvements have been confirmed by a wide range of published papers. Improvement of dimensional stability, increased electro-chemical corrosion resistance, toughness, ductility and other properties have been reported to improve after DCT.

- Available explanations for mechanism of DCT on the metallic material are grain refinement, precipitation of very fine carbides, refinement of retained austenite, transformation of austenite into martensite and amount of martensite in the matrix. The affecting mechanisms vary depending on the material type, grade and composition.

- Optimal parameters (soaking temperature, soaking time, cooling/warming rate, and tempering time) for each type of ferrous/non-ferrous alloys still have to be determined for easier and cost efficient applications in the industry.

- In future, the effectiveness of DCT must be explored more in depth and more systematically with experiments and modeling for ferrous and non-ferrous alloys to be procured and combined with detailed microstructural examination to clearly identify mechanisms responsible for change in material properties.

Author Contributions: P.J.-K. and B.P. prepared the manuscript, analyzed the data and prepared the plots. All authors have read and agreed to the published version of the manuscript.

Funding: The research project J2-9211 was funded by ARRS.

Conflicts of Interest: The authors declare no conflict of interest.

\section{References}

1. Barron, R.F. Do treatment at temperature below-120 F help increase the wear resistance of tool steels? Here are some research findings that indicate they do. Heat Treat. 1974, 5, 14-17.

2. Iacopi, F.; Choi, J.H.; Terashima, K.; Rice, P.M.; Dubois, G. Cryogenic plasmas for controlled processing of nanoporous materials. Phys. Chem. Chem. Phys. 2011, 13, 3634-3637. [CrossRef] [PubMed]

3. Prudhvi, K.; Lakshmi, V.V. Cryogenic tool treatment. Imp. J. Interdiscip. Res. 2016, 2, 1204-1211.

4. Rush, H.F. Cryogenic Material Selection, Availability, and Cost Considerations; NASA: Washington, WA, USA, 1983.

5. Orłowicz, A.W.; Mróz, M.; Tupaj, M.; Trytek, A. Materials used in the automotive industry. Arch. Foundry Eng. 2015, 15, 75-78. [CrossRef]

6. Singh, M. Application of steel in automotive industry. Int. J. Emerg. Technol. Adv. Eng. 2016, 6, $246-253$. 
7. Barron, R.F. Cryogenic treatment of metals to improve wear resistance. Cryogenics 1982, 22, $409-413$. [CrossRef]

8. Baldissera, P.; Delprete, C. Deep cryogenic treatment: A bibliographic review. Open Mech. Eng. J. 2008, 2, 1-11. [CrossRef]

9. Dumasia, C.A.; Kulkarni, V.A.; Sonar, K. A Review on the effect of cryogenic treatment on metals. Int. Res. J. Eng. Technol. 2017, 4, 2402-2406.

10. Podgornik, B.; Paulin, I.; Zajec, B.; Jacobson, S.; Leskovšek, V. Deep cryogenic treatment of tool steels. J. Mater. Process. Technol. 2016, 229, 398-406. [CrossRef]

11. Gogte, C.L.; Likhite, A.; Peshwe, D.; Bhokarikar, A.; Shetty, R. Effect of cryogenic processing on surface roughness of age hardenable AA6061 alloy. Mater. Manuf. Process. 2014, 29, 710-714. [CrossRef]

12. Indumathi, J.; Bijwe, J.; Ghosh, A.K.; Fahim, M.; Krishnaraj, N. Wear of Cryo-treated engineering polymers and composites. Wear 1999, 225-229, 343-353. [CrossRef]

13. Bensely, A.; Prabhakaran, A.; Mohan Lal, D.; Nagarajan, G. Enhancing the wear resistance of case carburized steel (En 353) by cryogenic treatment. Cryogenics 2006, 45, 747-754. [CrossRef]

14. Reitz, W.; Pendray, J. Cryoprocessing of materials: A review of current status. Mater. Manuf. Process. 2001, 16, 829-840. [CrossRef]

15. Gill, S.S.; Singh, H.; Singh, R.; Singh, J. Cryoprocessing of cutting tool materials-A review. Int. J. Adv. Manuf. Technol. 2010, 48, 175-192. [CrossRef]

16. Cicek, A.; KIvak, T.; Uygur, I.; Ekici, E.; Turgut, Y. Performance of cryogenically treated M35 HSS drills in drilling of austenitic stainless steels. Int. J. Adv. Manuf. Technol. 2012, 60, 65-73. [CrossRef]

17. Leskovšek, V.; Podgornik, B. Vacuum heat treatment, deep cryogenic treatment and simultaneous pulse plasma nitriding and tempering of P/M S390MC steel. Mater. Sci. Eng. A 2012, 531, 119-129. [CrossRef]

18. Gobbi, S.J.; Gobbi, V.J.; Reinke, G. Ultra low temperature process effects on micro-scale abrasion of tool steel AISI D2. Mater. Sci. Technol. 2019, 35, 1355-1364. [CrossRef]

19. Bartolomé, E.; Bozzo, B.; Sevilla, P.; Martínez-Pasarell, O.; Puig, T.; Granados, X. ABS 3D printed solutions for cryogenic applications. Cryogenics 2017, 82, 30-37. [CrossRef]

20. Zhisheng, W.; Ping, S.; Jinrui, L.; Shengsun, H. Effect of deep cryogenic treatment on electrode life and microstructure for spot welding hot dip galvanized steel. Mater. Des. 2003, 24, 687-692. [CrossRef]

21. Lin, Y.T.; Wang, M.C.; Zhang, Y.; He, Y.Z.; Wang, D.P. Investigation of microstructure evolution after post-weld Heat Treat. ment and cryogenic fracture toughness of the weld metal of AA2219 VPTIG joints. Mater. Des. 2017, 113, 54-59. [CrossRef]

22. Paul, S.; Chattopadhyay, A.B. Environmentally conscious machining and grinding with cryogenic cooling. Mach. Sci. Technol. 2007, 10, 87-131. [CrossRef]

23. Govindaraju, N.; Shakeel, A.L.; Pradeep Kumar, M. Experimental investigations on cryogenic cooling in the drilling of AISI 1045 Steel. Mater. Manuf. Process. 2014, 29, 1417-1421. [CrossRef]

24. Su, Y.; He, N.; Li, L.; Zhao, W. Effects of cryogenic nitrogen gas jet on machinability of Ti-alloy in high speed milling. China Mech. Eng. 2006, 17, 1183-1187.

25. Pérez, M.; Rodríguez, C.; Belzunce, F.J. The use of cryogenic thermal treatments to increase the fracture toughness of a hot work tool steel used to make forging dies. Procedia Mater. Sci. 2014, 3, 604-609. [CrossRef]

26. La Rocca, A.; Di Liberto, G.; Shayler, P.J.; Fay, M.W. The nanostructure of soot-in-oil particles and agglomerates from an automotive diesel engine. Tribol. Int. 2013, 61, 80-87. [CrossRef]

27. Senthilkumar, D. Thermophysical behavior of cryogenically treated silicon carbide for nanofluids. Mater. Manuf. Process. 2014, 29, 819-825. [CrossRef]

28. Mohan Lal, D.; Renganarayanan, S.; Kalanidhi, A. Cryogenic treatment to augment wear resistance of tool and die steels. Cryogenics 2001, 41, 149-155. [CrossRef]

29. Timmerhaus, K.D. Superconductivity. In Advances in Cryogenic Engineering; Springer: Berlin/Heidelberg, Germany, 1960; pp. 145-148. ISBN 9781461292999.

30. Timmerhaus, K.D.; Flynn, T.M. Properties of cryogenic fluids. In Cryogenic Process Engineering; Springer: Berlin/Heidelberg, Germany, 1989; pp. 13-38. ISBN 978-1-4684-8758-9.

31. Brown, W.L. The Development of Lubricants for Automotive A/C Systems; Purdue University: West Lafayette, IN, USA, 1998.

32. Podgornik, B.; Borovšak, U.; Megušar, F.; Košir, K. Performance of low-friction coatings in helium environments. Surf. Coat. Technol. 2012, 206, 4651-4658. [CrossRef] 
33. Pušavec, F.; Stoić, A.; Kopač, J. The role of cryogenics in machining processes. Teh. Vjesn. 2009, 16, 3-10.

34. Molinari, A.; Pellizzari, M.; Gialanella, S.; Straffelini, G.; Stiasny, K.H. Effect of deep cryogenic treatment on the mechanical properties of tool steels. J. Mater. Process. Technol. 2001, 118, 350-355. [CrossRef]

35. Behera, A.; Mishra, S.C. Comparative study of cryo -treated steel. Int. J. Sci. Technol. Res. 2012, 1, 46-49.

36. Barron, R.F.; Burt, W.; Byrns, R.; Clapp, M.; Clark, A.; Daniels, A.; Frederking, T.; Hassenzahll, W.; Kittell, P.; Klipping, C.; et al. Cryogenic engineering conference/international cryogenic materials conference. Boston, MA, USA. Cryogenics 1986, 26, 49-51. [CrossRef]

37. Wilkins, C. Cryogenic Processing: The Big Chill; EDM Today: Essex, CT, USA, 1999; pp. 36-44.

38. Timmerhaus, K.D.; Flynn, T.M. Cryogenic process engineering. In Encyclopedia of Physical Science and Technology; Academic Press: Cambridge, MA, USA, 2003; pp. 13-36. ISBN 9780122274107.

39. Barron, R.F.; Thompson, R.H. Effect of cryogenic treatment of corrosion resistance. In Proceedings of the International Cryogenics Materials Conference, Garmisch-Partenkirchen, Germany, 9-11 May 1990; Volume 17, pp. 1-6.

40. Thornton, R.; Slatter, T.; Jones, A.H.; Lewis, R. The effects of cryogenic processing on the wear resistance of grey cast iron brake discs. Wear 2011, 271, 2386-2395. [CrossRef]

41. Ming, C.J.E.R. Cryogenic Treatment of Music Wire. Master's Thesis, Department of Mechanical Engineering, National University of Singapore, Singapore, 2004.

42. Jurči, P.; Ptačinová, J.; Sahul, M.; Dománková, M.; Dlouhy, I. Metallurgical principles of microstructure formation in sub-zero treated cold-work tool steels-A review. Matér. Tech. 2018, 106, 104-113. [CrossRef]

43. Das, D.; Dutta, A.K.; Ray, K.K. Influence of varied cryotreatment on the wear behavior of AISI D2 steel. Wear 2009, 266, 297-309. [CrossRef]

44. Das, D.; Dutta, A.K.; Ray, K.K. Sub-zero treatments of AISI D2 steel: Part I. Microstructure and hardness. Mater. Sci. Eng. A 2010, 527, 2182-2193. [CrossRef]

45. Das, D.; Dutta, A.K.; Ray, K.K. Sub-zero treatments of AISI D2 steel: Part II. Wear behavior. Mater. Sci. Eng. A 2010, 527, 2194-2206. [CrossRef]

46. Senthilkumar, D. Cryogenic treatment: Shallow and deep. In Encyclopedia of Iron, Steel, and Their Alloys; CRC: Boca Raton, FL, USA, 2016; pp. 995-1007.

47. Niessen, F.; Villa, M.; Somers, M.A.J. Martensite formation from reverted austenite at sub-zero celsius temperature. Metall. Mater. Transact. A 2018, 49, 5241-5245. [CrossRef]

48. Surberg, C.H.; Stratton, P.; Lingenhöle, K. Effect of deep cold treatment on two case hardening steels. Acta Metall. Sin. Engl. Lett. 2008, 21, 1-7. [CrossRef]

49. Collins, D.N. Deep cryogenic treatment of tool steels: A review. Heat Treat. Met. 2010, 23, 40-42.

50. Diekman, F. Cold and cryogenic treatment of steel. In Steel Heat Treating Fundamentals and Processes-ASM Handbook; ASM International: Cleveland, OH, USA, 2013; pp. 382-386.

51. Jones, J.N.; Rogers, C.B. The acoustic effect of cryogenically treating. J. Acoust. Soc. Am. 2013, 114, 2349.

52. Sonar, T.; Lomte, S.; Gogte, C. Cryogenic treatment of metal-A review. In Materials Today; Elsevier Ltd.: Amsterdam, The Netherlands, 2018; Volume 5, pp. 25219-25228.

53. Dhokey, N.B.; Hake, A.R.; Thavale, V.T.; Gite, R.; Batheja, R. Microstructure and mechanical properties of cryotreated SAE8620 and D3 steels. Curr. Adv. Mater. Sci. Res. CAMSR Microstruct. 2014, 1, 23-27.

54. Dhokey, N.B.; Dandawate, J.V.; Rawat, R.; Dhokey, N.B.; Dandawate, J.V.; Rawat, R. Effect of cryosoaking time on transition in wear mechanism of M2 tool steel. ISRN Tribol. 2013, 2013, 1-6. [CrossRef]

55. Kalia, S. Cryogenic processing: A study of materials at low temperatures. J. Low Temp. Phys. 2010, 158, 934-945. [CrossRef]

56. Joshi, P.; Singh, J.; Dhiman, P.; Shekhar, H.; Kumar, V. Effect of cryogenic treatment on various materials: A review. Open Int. J. Technol. Innov. Res. 2015, 14, 1-11.

57. Darwin, J.D.; Mohan Lal, D.; Nagarajan, G. Optimization of cryogenic treatment to maximize the wear resistance of $18 \% \mathrm{Cr}$ martensitic stainless steel by Taguchi method. J. Mater. Process. Technol. 2008, 195, 241-247. [CrossRef]

58. Kumar, T.V.; Thirumurugan, R.; Viswanath, B. Influence of cryogenic treatment on the metallurgy of ferrous alloys: A review. Mater. Manuf. Process. 2017, 32, 1789-1805. [CrossRef]

59. Jovičević-Klug, P.; Podgornik, B. Deep cryogenic treatment of metallic materials in automotive applications: A review. In Proceedings of the ECHT 2019, Bardolino, Italy, 5-7 June 2019; pp. 1-10. 
60. Surberg, C.H.; Stratton, P.F.; Lingenhöle, K. The effect of cryogenic treatment on the properties of AISI D2. Mater. Manuf. Process. 2009, 24, 863-867. [CrossRef]

61. Villa, M.; Somers, M.A.J. Cryogenic treatment of steel: From concept to metallurgical understanding. In Proceedings of the 24th International Feration for Heat Treatment and Surface Engineering Congress, Nice, France, 26-29 June 2017.

62. Zurecki, Z. Cryogenic Quenching of Steel Revisited; Air Products and Chemicals, Inc.: Allentown, PA, USA, 2005; pp. 1-9.

63. Pellizzari, M. Influence of deep cryogenic treatment on the properties of conventional and PM high speed steels. Metall. Ital. 2008, 100, 17-22.

64. Collins, D.N.; Dormer, J. Deep cryogenic treatment of a D2 cold-work tool steel. Heat Treat. Met. 1997, $3,71-74$.

65. Yan, X.G.; Li, D.Y. Effects of the sub-zero treatment condition on microstructure, mechanical behavior and wear resistance of W9Mo3Cr4V high speed steel. Wear 2013, 302, 854-862. [CrossRef]

66. Chaudhari, S.N.; Vikhe, G.J. Deep cryogenic processing after heat treatment: A new approach. IJES 2013, 2, 246-249.

67. Ciski, A.; Nawrocki, P.; Babul, T.; Hradil, D. Multistage cryogenic treatment of X153CrMoV12 cold work steel. In Proceedings of the International Conference Recent Trends in Structural Materials IOP, Pilsen, Czech Republic, 14-16 November 2018; Volume 461, pp. 1-6.

68. Alava, L.A.; Artola, G.; Guinea, I.; Muro, M. On the influence of cryogenic steps on heat treatment processes. Mater. Perform. Charact. 2017, 6, 837-849. [CrossRef]

69. DeCicco, J.M. Steel and Iron Technologies for Automotive Lightweighting, Environmental Defense; University of Michigan: Ann Arbor, MI, USA, 2005.

70. Available online: www.worldsteel.org (accessed on 25 March 2020).

71. Berladir, K.V.; Rudenko, S.G.; Pererva, V.I.; Hovorun, T.P.; Martynov, A.I. Modern materials for automotive industry. J. Eng. Sci. 2018, 4, f8-f18.

72. Jaswin, A.; Dhasan, M.L. Effect of cryogenic treatment on corrosion resistance and thermal expansion of valve steels. Int. J. Eng. Technol. Manag. Appl. Sci. 2015, 3, 2349-4476.

73. Hu, F.; Wu, K.; Hodgson, P.D.; Shirzadi, A.A. Refinement of retained austenite in super-bainitic steel by a deep cryogenic treatment. ISIJ Int. 2014, 54, 222-226. [CrossRef]

74. Zhirafar, S.; Rezaeian, A.; Pugh, M. Effect of cryogenic treatment on the mechanical properties of 4340 steel. J. Mater. Process. Technol. 2007, 186, 298-303. [CrossRef]

75. Senthilkumar, D.; Rajendran, I.; Pellizzari, M.; Siiriainen, J. Influence of shallow and deep cryogenic treatment on the residual state of stress of 4140 steel. J. Mater. Process. Technol. 2011, 211, 396-401. [CrossRef]

76. Bensely, A.; Senthilkumar, D.; Mohan Lal, D.; Nagarajan, G.; Rajadurai, A. Effect of cryogenic treatment on tensile behavior of case carburized steel-815M17. Mater. Charact. 2007, 58, 485-491. [CrossRef]

77. Surberg, C.H.; Stratton, P.; Lingenhöle, E. The influence of cold treatment on case-hardened steel. Heat Treat. Prog. 2008, 8, 45-48.

78. Bilmes, P.D.; Solari, M.; Llorente, C.L. Characteristics and effects of austenite resulting from tempering of 13Cr-NiMo martensitic steel weld metals. Mater. Charact. 2001, 46, 285-296. [CrossRef]

79. Carrouge, D.; Bhadeshia, H.K.D.H.; Woolin, P. Effect of $\delta$-ferrite on impact properties of supermartensitic stainless steel heat affected zones. Sci. Technol. Weld. Join. 2004, 4, 377-389. [CrossRef]

80. Fentahun, M.A. Materials used in automotive manufacture and material selection using ashby charts. Int. J. Mater. Eng. 2018, 8, 40-54.

81. Ramdan, R.D.; Jauhari, I.; Izman, S.; Kadir, M.R.A.; Prawara, B.; Hamzah, E.; Nur, H. Shear mechanisms during cryogenic treatment of Ti6Al4V. In Proceedings of the 12th International Conference on QiR (Quality in Research), Bali, Indonesia, 4-7 July 2011; pp. 1390-1396.

82. Hu, Z.; Zheng, H.; Liu, G.; Wu, H. Effects of cryogenic treatment after annealing of Ti-6Al-4V alloy sheet on its formability at room temperature. Metals 2018, 8, 295. [CrossRef]

83. Gu, K.X.; Li, Z.Q.; Wang, J.J.; Zhou, Y.; Zhang, H.; Zhao, B.; Ji, W. The effect of cryogenic treatment on the microstructure and properties of Ti-6Al-4V titanium alloy. Mater. Sci. Forum 2013, 747-748, 899-903. [CrossRef]

84. Park, D.H.; Choi, S.W.; Kim, J.H.; Lee, J.M. Cryogenic mechanical behavior of 5000- and 6000-series aluminum alloys: Issues on application to offshore plants. Cryogenics 2015, 68, 44-58. [CrossRef] 
85. Asl, K.M.; Tari, A.; Khomamizadeh, F. Effect of deep cryogenic treatment on microstructure, creep and wear behaviors of AZ91 magnesium alloy. Mater. Sci. Eng. A 2009, 523, 27-31. [CrossRef]

86. Anil Kumar, B.K.; Ananthaprasad, M.G.; Gopalakrishna, K. Action of cryogenic chill on mechanical properties of nickel alloy metal matrix composites. In Proceedings of the International Conference on Advances in Materials and Manufacturing Applications, Bangalore, India, 14-16 July 2016; pp. 1-11.

87. Chen, P.; Malone, T.; Torres, P.; Bond, R. Effects of cryogenic treatment on the residual stress, NASA. In Proceeding of the 4th Conference on Aerospace Materials, Processes and Environmental Technology, Huntsville, AL, USA, 18-20 September 2000; pp. 1-4.

88. Steier, F.V.; Ashiuchi, E.S.; Reißig, L.; Araújo, J.A. Effect of a deep cryogenic treatment on wear and microstructure of a 6101 aluminum alloy. Adv. Mater. Sci. Eng. 2016, 2016, 1-12. [CrossRef]

89. Ramdan, R.D.; Jauhari, I.; Izman, S.; Kadir, M.R.A.; Prawara, B.; Hamzah, E.; Nur, H.; Gu, K.X.; Li, Z.Q.; Wang, J.J.; et al. Shear mechanisms during cryogenic treatment of Ti6Al4V. Metals 2011, 8, 1390-1396.

90. Dellacorte, C. Nickel-titanium alloys: Corrosion proof alloys for space bearing components and mechanism applications. In Proceedings of the 40th Aerospace Mechanism Symposium, NASA, Merritt Island, FL, USA, 12-14 May 2010; pp. 293-300.

91. Myeong, T.H.; Yamabayashi, Y.; Shimojo, M.; Higo, Y. A new life extension method for high cycle fatigue using micro-martensitic transformation in an austenitic stainless steel 1This work was carried out as a part of the Ph.D. thesis of one of the authors (T.H.M.) 1. Int. J. Fatigue 1997, 19, 69-73. [CrossRef]

92. Meng, F.; Tagashira, K.; Sohma, H. Wear resistance and microstructure of cryogenic treated Fe-1.4Cr-1C bearing steel. Scr. Metall. Mater. 1994, 31, 865-868. [CrossRef]

93. Senthilkumar, D. Effect of deep cryogenic treatment on residual stress and mechanical behaviour of induction hardened En 8 steel. Adv. Mater. Process. Technol. 2016, 2, 427-436. [CrossRef]

94. Demir, E.; Toktas, I. Effects of cryogenic treatment on residual stresses of AISI D2 tool steel. Kov. Mater. 2018, 56, 153-161. [CrossRef]

95. Caballero, F.G.; Miller, M.K.; Garcia-Mateo, C. Carbon supersaturation of ferrite in a nanocrystalline bainitic steel. Acta Mater. 2010, 58, 2338-2343. [CrossRef]

96. Koneshlou, M.; Meshinchi, A.K.; Khomamizadeh, F. Effect of cryogenic tratment on microstucture, mechanical and wear behaviors of AISI H13 hot work tool steel. Cryogenics 2011, 51, 55-61. [CrossRef]

97. Landa, V.A. The secondary martensitic transformation resulting from tempering tool steels. Met. Sci. Heat Treat. 1963, 5, 125-129. [CrossRef]

(C) 2020 by the authors. Licensee MDPI, Basel, Switzerland. This article is an open access article distributed under the terms and conditions of the Creative Commons Attribution (CC BY) license (http://creativecommons.org/licenses/by/4.0/). 